\author{
THE CROWN IN NEW ZEALAND: \\ ANTHROPOLOGICAL PERSPECTIVES ON AN IMAGINED SOVEREIGN
}

Cris Shore \& Margaret Kawharu

\begin{abstract}
The 'Crown' in New Zealand is often seen as an essential partner in the Treaty of Waitangi relationship between Māori and the government, yet as some legal commentators have noted, the Crown itself is a 'legal fiction' and a 'shapeshifting' symbol whose definition is obtuse and whose meanings vary according to context. This article reports on an ethnographic study that examines how the concept of the Crown is understood and contested in New Zealand. It also examines the different ways in which the Crown as a political, legal and symbolic entity shapes policy and practice. We ask, what exactly is the Crown, how is it imagined and personified, when and why is the discourse of the Crown used, and what are the implications of its continual usage? We argue that the Crown is an imagined yet extraordinarily powerful entity that represents more than simply a proxy for the New Zealand state. It needs to be deconstructed in order to shed light on the symbolic and discursive work it performs in maintaining New Zealand's political and constitutional order. We also outline some of the key findings of our pilot study and suggest future directions for research.
\end{abstract}

\title{
INTRODUCTION: THE SHAPESHIFTING CROWN
}

The Crown lies at the heart of New Zealand's constitutional order and is often presented as an essential partner in the Treaty of Waitangi relationship yet, as former Attorney-General Margaret Wilson $(2011,1)$ notes, 'it is also a useful fiction that enables government to distance themselves from direct responsibility for obligations under the Treaty.' The implications of this contradiction are profound yet have rarely been explored: how can the Crown be both a core Treaty signatory and a 'useful fiction?' Legal scholars recognise that the Crown, as a metonym for government and the state, is a 'shapeshifting symbol' (Cox 2008), an abstract entity that historically embodied the British Empire but today serves as a compendious cloak for aligning archaic rules, ceremo- 
nies and meanings with the trappings of contemporary governmental authority (McLean 2008; McHugh and Ford 2013). But if the Crown 'has different meanings according to context,' as even the Supreme Court of New Zealand now acknowledges (2010), what exactly are those meanings and how does the Crown manifest itself in different contexts? How does this ambiguity affect those who deal with the Crown - either as plaintiffs or as officials - in its different guises? Perhaps more importantly, what does the shapeshifting nature of the Crown tell us about the character of the state in New Zealand and the practice (or art) of government? Despite major interest in the Crown as a legal concept in New Zealand, to date very little attention has been paid to how the Crown is personified and embodied or to its symbolic and semiotic character; that is, to the Crown as a cultural entity and social institution.

This article sets out to address these questions and fill that lacuna by examining how the concept of the Crown is understood and contested in New Zealand. In doing so, we report on an ethnographically informed pilot study carried out in 2012 involving both personal observations and in-depth interviews with Crown officials, legal and constitutional experts, politicians and Māori leaders. Our primary aim was to examine the different meanings that the Crown holds for legal and political elites in New Zealand; i.e., to understand how they imagine the Crown and the implications of these imaginaries. We also sought to analyse the different ways in which the rhetoric of the Crown is used to buttress authority, legitimize decision-making, and shape policy and practice. That interest was piqued by our observations of the curious and sometimes contradictory ways in which government ministers invoke 'the Crown' in their political oratory and public pronouncements. Sometimes ministers will speak to an issue of public policy as members of Parliament, the ruling National Party, the government, and as 'the Crown' itself - often oscillating between all four registers. This raises the question 'what exactly is the Crown' and when is that term used (or not used) in political and legal discourse? As we discovered, the Crown in New Zealand is typically taken for granted and treated as a given that requires little or no explanation. We therefore set out to deconstruct the Crown in order to shed light on its symbolic meanings and the discursive work that it performs in maintaining New Zealand's political and constitutional order.

Our argument is presented in four parts. First, we outline the methodology used in our study, the rationale for the research and the anthropological issues it raises. Our hypothesis is that the Crown, as proxy for state authority, provides a useful optic for understanding the changing nature of the state and nation in New Zealand, and may have significance for other post-colonial societies as well. Second, we ask, how should we conceptualise the Crown, how 
is it perceived, and why is defining and locating it problematic? Third, we draw on our fieldwork interviews and observations to examine people's understanding and experience of the Crown. We also examine some of the contradictory ways in which the Crown is made visible in New Zealand, how these different representations are interpreted and what they symbolize. Finally, we consider some of the ways in which the concept of the Crown is put to work in New Zealand public discourse - and with what implications.

THEORETICAL CONTEXT:

THE CROWN AS A WINDOW ON TO THE NEW ZEALAND STATE

The theoretical focus of this special issue of Sites is on the theme of the imagination' and, more specifically, social imaginaries. Within anthropology, following the pioneering work of Anderson (1983) and Gellner (1983), there is now an extensive literature on the relationship between social imaginaries and nationhood and, more specifically, on the idea of nations as imagined communities' that are 'imagined as both inherently limited and sovereign' (Anderson $1983,6)$. How nations are imagined, and by whom, has provided significant impetus for the development of political anthropology (Kelly and Kaplan 2001; Eriksen 2002). In recent years, however, the question of social imaginaries has also been extended to explore processes of state-formation and the problems of understanding the modern state (Steinmetz 1999; Trouillot 2001; Das and Poole 2004). In this article we take up these themes of social imaginaries but in the context of the New Zealand state which, we suggest, represents an exemplary illustration of the way that power is put to work in the construction of that imagined sphere commonly termed government or politics. As Michael Walzer eloquently wrote, 'the state is invisible; it must be personified before it can be seen, symbolised before it can be loved, imagined before it can be conceived' (Walzer 1967, 184). By that, Walzer was drawing attention to an idea that has become fairly axiomatic in social anthropology (yet curiously forgotten elsewhere) that political and social institutions have to be symbolically constructed if they are to have salience and legitimacy in people's lives. In short, rituals and symbols are central to the way in which political reality is constituted (Kertzer 1986).

As we set out to demonstrate below, the Crown is both a legal fiction and a manifestation of the state; an abstract construct and embodiment of a particular kind of executive and judicial authority. The operation of the Crown highlights many aspects of the way in which political power is symbolized, personified and disguised, but it also highlights the contradictions involved in trying to define or locate the Crown and map its powers. For example, legal 
scholar Janet McClean $(2008,35)$ recounts an interesting illustration of this problem:

A few years ago, I distinctly remember Mrs Tariana Turia, then the Associate Minister of Māori Affairs and a minister outside of Cabinet, being reported as suggesting that the Crown ought to be doing something to fulfil its commitments under the Treaty of Waitangi. It struck me that she referred to the Crown as if it were an apolitical entity quite distinct from Cabinet government and from her own role as minister. It was not 'we' but 'it' or 'they'.

Our findings revealed a similar process of strategic political positioning: not only is the Crown typically portrayed as 'Other', it is commonly viewed as a unified sovereign entity that stands above ministers, Parliament and the executive. Our research also highlighted a curious disjuncture between the status of the Crown as a legal and technical concept, and the extraordinarily symbolic significance and meanings that it holds for politicians and the public. For Māori in particular, the Crown is seen as both ally and enemy; as the face of both colonial and contemporary government in New Zealand, and as the arbiter of post-colonial justice.

LOCATING THE CROWN IN NEW ZEALAND: AIMS, SCOPE \& METHODOLOGY OF THE PROJECT

Our pilot study, carried out over eight months in 2012, set out to explore the idea of the Crown in New Zealand and the work it performs as a legal, political and symbolic entity. Our goal was to produce findings of relevance to wider debates over the past, present and future of government-iwi (tribe) relations. Unpacking the symbolism of the Crown, we hoped, would also cast light on the political uses of the term, on the different ways the Crown represents itself, and on contestations over the way it is perceived by different groups and experts. To do this we brought together legal perspectives on the Crown with anthropological and sociological approaches to symbolism, state power and governance (Cohen 1985; Mitchell 1991; Rose and Miller 1992; Shore 2006). This multidisciplinary approach enabled us to analyse the polysemic character of the Crown and to better understand its uses as a political technology. Our study was also original in forging a new research partnership between two professors from Auckland University's Faculty of Law (David Williams) and Department of Anthropology (Cris Shore) and two Māori researchers (Margaret Kawharu and Marama Muru-Lanning). 
As a pilot study the scope of the project was necessarily limited. The team split into two pairs (Shore and Kawharu, Williams and Muru-Lanning) each undertaking a series of fifteen to eighteen interviews with a total of thirty one key actors. We selected individuals with recognised expertise on Crown policies and practices who could offer distinctive perspectives on how the Crown is understood and contested. We also drew on our own experiences and personal networks, including Williams' first-hand knowledge of Waitangi Tribunal processes and Kawharu's many years of negotiating with the Crown to settle Ngati Whatua o Kaipara's historical Treaty of Waitangi claims (which were settled in 2011). Some of our interviewees therefore included people that we already knew well either in a personal or professional capacity. These included former Chief Crown negotiators, high court judges, legal experts, MPs and senior politicians including three party leaders, former Crown ministers, officials from the Office of Treaty Settlements, and three former Ministers for Treaty of Waitangi claim negotiations. Our interviewees included a balance of Māori and non-Māori, men and women, and a wide range of experts who had participated in Treaty settlements and Treaty education. A logical extension to the research would be to open the project to people from all walks of life in New Zealand and include ethnicities other than Māori and New Zealanders of European descent. ${ }^{1}$ For each interviewee we posed a similar set of questions, although many of these were deliberately open-ended. These included a focus on people's perceptions on the role and significance of the Crown (today and in the future), the meanings it holds for them, their personal experience of the Crown, and their observations on the different forms and contexts in which the Crown is manifest. We also asked informants whether they viewed the Crown as an impediment to constitutional reform and what place it would have if New Zealand becomes a republic.

All of our interviews were recorded and transcribed. This was important as it enabled us to capture the precise words that our informants used and the nuances of language, metaphor and expression, as well as the revealing silences and the uses of humour. Most of our interviews lasted over an hour, some stretching over two hours. The interviews were mostly conducted at the workplaces and offices of our research participants, including Parliament and regional high courts, sometimes in their homes with their families present or hovering in the background. We also supplemented these narrative accounts, wherever possible, with background archival research, news stories and background reports relevant to either the person being interviewed or the topics likely to be discussed. Most of our empirical data was derived from these $31 \mathrm{in}$ terviews. Some anthropologists might argue that the use of interviews as a primary source of data does not constitute a truly 'ethnographic' approach. Others 
would disagree, pointing out that interviews can indeed be ethnographic, and are sometimes even a form of 'talking partnership' (Rapport 2012; Skinner 2012). Our own view is that ethnography is not simply participant observation, just as anthropology is not simply the fieldwork method. The discipline has always been much more than its methods and good anthropological analysis requires us to go beyond empiricism, particularly when we are dealing with issues of state power and political symbols.

\section{WHAT IS THE CROWN? PROBLEMS OF DEFINITION}

I use the term 'the Crown' because that's the legal term, but I prefer to use 'the state.' I recently had a referee's report on an article I wrote for an international journal and the referee, who obviously didn't know anything about New Zealand, said something like, 'Well, I like the article but there's something weird about this guy, he doesn't seem to understand that there's no such thing as the Crown, doesn't he know that New Zealand became independent in the 1940s?'

As the anecdote above illustrates, in New Zealand the Crown is commonly used as an alternative to The State, yet its meanings are arguably both more complex and more obscure. Few terms appear more frequently in New Zealand legal and political discourse than the Crown: in land disputes, Treaty settlements, issues over coastal protection or fishing rights, the extraction of minerals, state-funded scientific research, or water privatisation - the Crown is a major actor in all of these fields of activity. Yet despite this seeming ubiquity, the definition of the Crown and its meanings remain obtuse. The simple question, 'what is the Crown?' produced a bewildering variety of answers from our expert interviewees, from 'Parliament and the government,' 'the executive' and 'a proxy for state power or sovereign authority,' to 'the Queen of England,' The English Monarchy,' and 'I've never really thought about it before,' which significantly was one of the most common responses. Most interviewees concurred that the definition of the Crown shifts according to context. As one High Court judge summed it up:

Sometimes the Crown is a political entity, a useful target against which to aim your bullets, sometimes it is a personal thing capable of maintaining a personalised relationship and that tends to be the traditional romanticised Māori view. Sometimes it's a legal entity, that's often when the politicians chop and change within Government and Crown. 
According to a former government minister, the Crown is 'the sovereign and source of all rights, the origins of which derive from absolute monarchy:

It's the symbolic head of state and whilst in the old days the sovereign could do what he or she liked, today she can't do anything without the consent or advice of her Cabinet, so the Crown is still the sovereign in law, but a sovereign who is told what to do by the government.

From this perspective, the Crown appears paradoxically to be both the ultimate source of legal authority yet, at the same time, a body that is subordinate to the will of ministers. While a number of interviewees noted the ambiguous nature of the Crown, for Treaty settlement negotiators and other Crown officials, there is a clear and technical definition which is set out in the Public Finance Act and Crown Proceedings Act according to which the Crown is the 'Sovereign in Right of New Zealand' and 'Her Majesty in Right of New Zealand,' including all ministers 'of the Crown' and departments of government - but not Parliament, Crown entities, state enterprises or the judiciary. ${ }^{2}$ In a strictly legal sense, the Crown is the legal embodiment of the state in its permanent form: an abstract entity that transcends the apparatus of government. However, as the Attorney General of New Zealand conceded, 'even in its own statutes the term is not entirely clear.'

\section{MĀORI PERCEPTIONS OF THE CROWN}

Our study found that the discourse of the Crown in New Zealand, particularly within government circles, appears to have increased during the 1980s, largely in response to Māori discourse on the Crown. As one minister observed, 'we talk about the Crown because Māori talk about the Crown.'This was corroborated by a number of academics. In the words of one eminent historian:

I think the increasing use of the term 'the Crown' came in the wake of government policy that was responding to the so-called Māori renaissance in the 1980 os. Once state officials started talking to Māori more, and Māori talked often about their partnership with the Crown since 1840 , it seems the government started to accommodate this perspective.

But the point here is also that the Crown is a labile and fluid concept. Like all key symbols, its power lies in its polysemous and ambiguous character and its capacity to condense meaning. In short, it has a spectrum of connotations 
and associations that shift according to context. As one Māori legal scholar and judge noted:

\begin{abstract}
There has always been a high tolerance for ambiguity in New Zealand and when Māori thought of the Crown initially in the 19th century they saw the Crown as something separate from the settlers ... Māori prefer to use the term Crown rather than Government or State and when they wish to criticise an official, they'll say, well you're just from the Crown. They'll adopt that bipolar approach. ... the effect is to 'other-ise' in a way that the 'other' is an arm of the oppressor. The Crown is power and oppressive power.
\end{abstract}

As the above illustrates, Mãori typically perceive the Crown as 'Other' and the term itself is often code for colonial oppression. In the words of a former Office of Treaty Settlements (отs) official, 'it is a metonym for white New Zealand historically ... a metaphor for all the terrible things that have ever been done by a government in New Zealand'.

Another former отs official recognised that there had been a long history of Crown negligence and incompetence that had resulted in Māori disenfranchisement. As a Crown negotiator, he experienced being at the receiving end of a considerable amount of invective from Māori claimants. We heard repeatedly how отs officials were positioned as the embodiment of the Crown. One official recalled an iwi leader giving an extremely angry speech and poking his finger at him saying:

'Look, this is what you did to us. You invaded us, you did this, you did that.' I remember thinking to myself 'God Almighty, I'm the historian who helped expose all these horrible things in the past and now I'm here, what am I doing here taking responsibility for them?' But then afterwards, he said, 'Okay, time for a cup of tea now.' And he rushed over to me and he took me aside and said, 'Of course, we know it's not you.' He said, 'We know the way you're arguing inside the Crown, we have members of our tribe who work inside the Crown, we know you're okay, but you are the Crown as far as my people are concerned so I really gave you a bollixing.' I said, 'Yeah that's fine,' because that's the way it is.

As the above shows, Māori claimants were very careful to emphasise that this was not a personal attack, that it was just how they viewed the Crown. No matter who, in the long succession of Crown officials, was representing the Crown, 
there was a sense among Māori of a continuum that linked back to the Queen of England and to the events of 1840 .

Paradoxically, although Māori often depict the Crown as colonial oppressor, they also typically portray the Treaty as a highly personal relationship almost akin to a marriage and an enduring kinship tie. One participant expressed it as follows:

they talk about the Treaty being a marriage and they mean it literally because this is how you create the necessary relationship and bonding. ... the tribe that displaces the other tribe simply takes over its whakapapa and therefore gets its primary right by virtue of its blend with the prior owner, not by virtue of its destruction of the prior owner and that's because ancestral right is always the dominant right on anything.

From a Māori perspective, the Treaty signifies a personal link with the Queen of England, from Queen Victoria to the present monarch, or as one historian put it,'a personal deal that is almost a sacred compact ... at the time there was a personal relationship established and the promises involved needed to be adhered to.'

Another interviewee noted that it was a political syndrome of Māori to want to believe in the purity and the nobility of the Crown because it held up certain standards of ethics and conduct for the government to attain in the name of the Crown. Thus the Crown is often treated as a symbolic or metaphorical entity with a transcendent dimension. Yet for most claimants the Crown is really the Minister of Treaty Negotiations who, in the absence of the Queen or the Governor General, 'is the personification of the Crown.' Obtaining a meeting with the minister is typically seen as the ultimate achievement for most claimants. As one experienced Treaty negotiator said, 'when you're meeting with the minister you're almost certainly not going to be able to go higher ... so you don't want to use them too often.' Indeed, part of the idea behind establishing the Chief Crown Negotiator role was to achieve a degree of seniority, closeness to power and decision making, and connection with the minister:

It was a role created to help distinguish between the bureaucracy, the officials and the representative of the Queen, of the minister ... Treaty settlements are essentially contracts between cabinet, ministers and the claimant group. Arguably the real Crown stamp of approval comes from Parliament. 
However, this begs the question of where the Crown begins and ends and the extent to which Parliament can be said to control the Crown, or vice-versa.

HOW IS THE CROWN PERCEIVED BY NON-MĀORI?

Our study showed that while the notion of the Crown was significant for Māori, it also played an important role in New Zealand's evolution from a small colony to an independent and fully-fledged nation-state with its own distinct identity. A very experienced Treaty lawyer who spent years representing Māori claimants was reassured by the role of Crown Law in the settlement process because, as he put it, 'unless Crown Law did its job properly, you would have a process without integrity. In this sense Crown Law represented and protected him and his integrity as a non-Māori, and therefore demonstrated the Crown's leadership role.

I think there's an ill-defined but important sense of New Zealand that the Crown has facilitated, and from there it's always important to have somebody you can take an issue to.

The challenge, according to one historian, was to work out how the relationship between Māori and the Crown in 1840 gets worked through in the modern world in a way that can accommodate democracy and give voice to different ethnicities and cultures. A member of the former Treaty of Waitangi policy unit within the Ministry of Justice specifically recalled a policy being agreed in 1989 that the settlement process would not throw into question private lands. The consensus view then (and now) was that Treaty settlements should not create further injustices either to claimant groups or to anyone else because the Crown has a duty to act in the best interest of all New Zealanders:

There was a legislative amendment to make sure the Waitangi Tribunal couldn't recommend the return of private land. And I was completely in support of that. And indeed various claimant groups were also in support. Kaumatua and kuia [Māori elders] would say, 'Look we don't want any rocking of the boat here, we have to live with the Pakeha here, we've been developing relations with them decade after decade, things are going quite well, we don't want policies which wreck that, 'cause day to day living is what counts. An apology from the Queen would be lovely, compo' for past grievances would be great, but hey, we're here and we have to live here.'

The role of the Crown for non-Māori and Māori alike is therefore steeped in 
ideals of a detached, higher authority to whom one can appeal to for justice. As one high court judge told us, in New Zealand, unlike the United States, the idea that the State does everything for the people is 'deep in our DNA.' His explanation for this was because:

New Zealand was the first western socialist state. It was the state, not private companies, that built the railroads, that created laws, and taxed everyone to within an inch of their lives in order to provide free healthcare, free education, free milk etc. And we stayed that way really until [the State Owned Enterprise Act of] 1987.

Even today, to the extent that people think about the Crown at all, it is commonly viewed as a supreme authority located above the fray of everyday political interests. Yet for many New Zealanders the Crown also symbolizes a connection with something bigger than the nation state itself.

If you are concerned about a decision that a judge has made about you or you think you have been arrested wrongfully or you are concerned about the level of representation in Parliament, your plea will be to the Crown. You need to override these sorts of temporary expedient people and go to a more durable lasting source of authority.

Until the 2003 Supreme Court Act that 'durable lasting source of authority' was the Privy Council in London, which for New Zealanders was the highest level of judicial appeal.'Her Majesty's Most Honourable Privy Council', to give it its proper title, was the body of senior advisors traditionally charged with advising the Sovereign on the exercise of Royal Prerogative. The reason for this, it was explained to us, was because in medieval England, the Sovereign always sought advice from the Privy Council and the Cabinet was merely one of several committees of the Privy Council, all of which were subordinate to the absolute monarch. In England, cabinet ministers are always members of the Privy Council, hence their title, 'the Right Honourable.' In New Zealand, Cabinet ministers are not members of the Privy Council but they nonetheless have the historical title of the Right Honourable and the sovereign is the Queen in Right of New Zealand. With the rise of democracy and the remoteness of the Sovereign, the monarchy has been relegated to a symbolic Crown which acts on instructions from the government. As one former Cabinet Minister expressed it:

She sacks people, appoints judges, appoints members of Parliament, members of the council, Privy Council, cabinet, but she's told who 
to appoint. But that doesn't take away the fact that that's where the sovereign is, that is the Crown. So when people say, 'Well the Crown's really the government,' well it is in the sense that that's where power lies, but legally it's not, there is a difference between the two.

The notion of the Crown still carries many of the associations of an English feudal sovereign whose role is to protect his or her subjects in return for their loyalty. In New Zealand the Crown is still seen by both Māori and non-Māori as a kind of protectorate of its citizens, hence its most visible presence in agencies such as Child Youth and Family, the New Zealand Defense Forces, Customs Control and Border Security and the police.

HOW THE CROWN IS PERSONIFIED

If the Crown is typically construed as a singular unified institution and abstract entity that stands above the realm of everyday government, it is nonetheless experienced in its more prosaic and embodied manifestations. Typically, these manifestations of the Crown include individuals as well as institutions and symbols. The Crown is most visibly personified in the figure of the Governor General of New Zealand, who at the time of writing is Sir Jerry Mataparae, a former Chief of the New Zealand Defence Force with the rank of Lieutenant-General. Significantly, Sir Jerry is the second Governor-General of Māori descent; his tribal affiliations are to Ngāti Tūwharetoa and Ngāti Kahungunu. This adds an interesting dimension to the stereotypical image of the Crown as the representative of colonialism or Pakeha New Zealand. From a legal perspective, the personification of the Crown makes no distinction on the grounds of ethnicity.

Even government ministers we interviewed were sometimes uncertain as to when exactly they embodied the Crown. As the Attorney General put it, 'when I am talking about funding the arts, I don't talk about the Crown. When one is dealing with important constitutional issues, like entering into deeds of settlement for historical grievances with iwi, I do.' The co-leader of the Māori Party, Dr. Pita Sharples, expressed uncertainty as to whether his role as a minister in the government made him part of the New Zealand Crown or not: 'Two of us have ministerial positions. Are we part of the Crown, or are we just add-ons? Are they Crown positions or government positions?' As he noted, it is Cabinet that makes policy decisions and sometimes he is involved and often not. For Dr. Sharples, the Crown signifies a level above local elected members of Parliament and an entity that is separate from Mãori yet integral to the attainment of Māori aspirations. The Crown is typically appealed to as the arbiter in the 
search for justice. Paradoxically, it is also very often the perpetrator of historical injustices which the Crown itself must acknowledge and redress. In this sense, he concluded, 'it is both an ally and the enemy as well.'

A key issue in current debates over the Crown in New Zealand is not so much the problem of defining what the Crown is, but deciding where it begins and ends. There is a tendency to use the term 'the Crown' in a way that excludes the judiciary. As one senior law professor noted:

Generally lawyers would not be prepared to accept that the Crown includes the courts - even though the government appoints the judges, but they can be removed by Parliament. But generally under the doctrine of the separation of powers we would say that the judiciary really is separate from the Crown, it's part of that overall machine of government, but you wouldn't ordinarily call it the Crown.

However, some historians and academics take a different view.

The judiciary are part of the state apparatus and at the end of the day an ordinary citizen is faced with the authorities doing something to them or incarcerating them, and that's done in the name of the Crown. So I think it's complete nonsense to say the judiciary aren't part of the Crown, because clearly in other countries the judiciary are part of the state.

Similar problems surround the question of whether local government is, strictly speaking, part of the Crown. Here again the answer appears to be ambiguous and variable. The purist view is that local government simply exercises delegated functions from central government; it carries out a strictly subordinate role. While it is certainly an agency of the Crown, its powers are very circumscribed and governed by Statute law. The Crown, on the other hand, has prerogative powers that are not controlled by any single legal instrument. The problem with this distinction is that while local government has consistently whittled away reserve land important to Māori hapu (clans) and iwi, there is no possibility of taking a claim against a local government because it is deemed not to be part of the Crown. Clearly, local government structures - including Auckland and Wellington city councils - which were created by the Crown under delegated authority, have a major impact on people and land. As a Chief Crown Negotiator observed:

I find it a bit of a fiction that local government isn't the Crown. When 
local government gets into housing and social services, they're doing things that the Crown has asked them to do and that the Crown also does. So there's a challenging tension there.

And yet, as he later observed, this model works for the purpose of Treaty negotiations because 'we don't really want to be in a position of trying to force local governments to hand over land.'

THE INDIVISIBILITY OF THE CROWN

A key aspect of the New Zealand constitutional order is the doctrine of the 'indivisibility of the Crown.' This idea has long served as a device that lends authority and legitimacy to decisions made by government. The Crown, as it were, is the body that validates state authority. As the Attorney General put it:

the Crown, is the Crown, is the Crown ... You can't have government departments as warring factions because they are all emanations of the one Crown.... it's a constitutional absurdity, for government departments to be for example in the Environment Court taking different positions. You can't have it. There's one Crown. There can only be one view. That's not to say it doesn't happen.

Despite this admission that the Crown can, at times, speak with different voices, a former отs official acknowledged that there is a real imperative to come across as united' particularly when fronting up to claimants in a settlement negotiation. This also occurs in other areas of government:

It's no secret that we have, shall we say, a very interesting series of discussions with the Department of Conservation because I take the view, and I'm constitutionally absolutely correct, the Department of Conservation is a department of state, an emanation of the Crown, which is charged with among other things advocating for conservation and also looking after the Crown estate. There is no such thing as the DOC estate. It is a constitutional and legal impossibility.

The reality is that when ministers disagree it is up to the Cabinet to arbitrate and 'then there will be a Crown view, but a Crown view is not immutable; it changes a lot as ministers seek advice.' As one former minister reflected, 'ministers having different points of view does not necessarily mean the Crown is divided.' Having to articulate or defend the Crown's point of view can be problematic for Crown officials: 
In settlement negotiations we talk about the indivisible Crown, but there are many instances where I have to defend positions I don't personally agree with, I have to own the policies and practices that underpin the Crown. But certainly the idea of the Crown as a single entity presenting a unified front is very, very important.

However, officials often have to deal with the reality of a Crown that at times is divided. A lawyer for one Māori claimant group observed:

From the claimants point of view you may have one part of the Crown on board, such as the отs, who have a peculiar role because they are opposed to you until you've got an agreement in principle, and then they're trying to nail down the agreement. In this case the отs is actually taking your part against the rest of the Crown, which raises all sorts of ideas about a house divided. But if we see at meetings the Ministry of Education or Land Information New Zealand taking an unreasonable position, suddenly you can see the differences between the Crown. And then you realise that actually it's all made up of individuals and actually there is no Crown as such.

The conclusion, it seems, is that the Crown is very much shaped and rendered concrete by the personalities of those individuals who represent it. Little wonder, therefore, that it is seen as a shape-shifting entity. As one constitutional historian declared, 'sometimes the state is indivisible, sometimes sovereignty is indivisible, sometimes it isn't, depending on who's arguing what and what their ultimate purpose is.'

From an anthropological perspective, the idea of a unified and historically coherent and indivisible Crown, it seems, fulfils a number of legal and political purposes concerned with legitimising certain actions of government. But it also helps to sustain ideas of New Zealand nationhood and identity. Not only does the Crown provide a sense of historical and material continuity and connection with something larger than itself (i.e., Britain and the Commonwealth), it also 'diminishes the sense of isolation' that arises from New Zealand's remote location.

However, the idea of a unified and continuous Crown is problematic for anthropologists and historians as it conceals as much as it reveals. 'As a historian I find that the use of the rhetoric of the Crown unhelpful,' declared one interviewee: 
It obscures the complexity of our history.... It means we avoid looking at policies of particular regimes, particular governments, and don't need to understand the nuances of our colonial politics. It's very important to chart these, so that we understand our history as a political history, not just as a litany of things that the Crown did or didn't do - which creates a false impression of a monolithic uniformity about what happened in our past with the Crown.

For historians, the rhetoric of the Crown, particularly in Treaty claim reports to the Waitangi Tribunal, produces a 'very flat kind of narrative' and the reports themselves are often 'incredibly boring' as a result.

THE CROWN: AN OBSTACLE TO CONSTITUTIONAL REFORM?

Given these many ambiguities, contradictions and problems of definition, why does the discourse of the Crown continue to have such importance in New Zealand? Is its continuing use an impediment to constitutional reform and to New Zealand becoming a republic? On these issues, our informants were divided. From our interviews, at least six key arguments concerning the implications of constitutional reform emerged. First, for Māori the existence of the Crown serves to give the Treaty relationship binding importance. Were New Zealand to become a republic, many feared that this could erode Treaty rights and negate the obligations between Crown and Māori. As the Minister for Māori affairs pointed out, to go forward, there would have to be an acceptance of the Treaty as a founding document and the constitutional basis of government in New Zealand. The current contractual relationship between the Crown and Māori - and the rights and privileges - would have to be transferred to the state and written into a new constitution. Although as one high court judge surmised, reflecting on the processes of hybridization underway in New Zealand culture and society, 'if you take the indigenization of the state to its logical endpoint, it could not be done without the removal of the Crown.'

A second argument against New Zealand becoming a republic is that the office of a president as head of state, the transfer of powers and the codification of rights and obligations would be a hugely difficult technical operation - and also very costly. As the Attorney General pointed out, 'the present arrangements are kind of clever. There are some things you just can't create de novo.' He also noted that the New Zealand's historical connection with the Crown is a major source of the government's enduring authority and legitimacy. For example, it is from the Treaty that the Crown acquired its right to govern - in exchange for protection (i.e., its fiduciary role). While this may seem like an 
obsolete and outmoded notion, it nevertheless highlights the genealogy of sovereign authority in NZ.

A third argument concerns international relations. A former minister of Foreign Affairs also noted that the current arrangement is what gives New Zealand a seat at the table with the Commonwealth, a partnership with 'one quarter of the world's population' that 'costs us nothing.' As one judge expressed it somewhat bluntly: 'if we have a President we're really on our own at the arse end of the world and we've always feared that and that's why it's so hard because our life depends on us belonging to somebody else.'

Others argued that leaving those constitutional and Treaty rights open to be contested and to evolve is preferable to prescribing them narrowly in some fixed written constitution. In short, the current arrangements lend flexibility to New Zealand's constitutional form which serves useful political functions and appeals to the country's reputed pragmatism. A fifth argument was that New Zealanders are 'terminally lethargic' about these grand constitutional issues, 'but they like being attached' to their historical traditions, which include monarchy. A shift to becoming a republic was perceived by many as 'cutting the umbilical cord' between New Zealand and not only 'mother England' but beyond this to the tradition that emanates from 'Christian civilization' itself, a move that would isolate the country symbolically as well as geographically. Still others contended that becoming a republic would not actually change anything of substance, as was illustrated in the case of Ireland. New Zealand would substitute the Crown for a head of state and a different structure, but 'the Crown's prerogative to grant rights would pass to central government. That doesn't mean that customary rights and indigenous rights have gone. It just means that you're enforcing them against somebody else who is meant to be recognising them.'

\section{CONCLUSIONS: THE CROWN - A USEFUL BUT PROBLEMATIC FICTION}

Our ethnographic enquiry into the nature of the Crown confirms the Supreme Court of New Zealand's somewhat unsettling acknowledgement that definitions of the Crown 'shift according to context', as do perceptions of the Crown. The Crown, it seems, has many faces. Sometimes it is the Queen of England (whose face adorns our coins and banknotes) or members of the Royal Family on a state visit to the country; sometimes it is the Governor General of New Zealand presiding over ceremonial state occasions; and sometimes it is the Attorney General and the office of Crown Law - that body whose mandate is to ensure that the operations and responsibilities of the executive government 
are conducted lawfully' (Ministry of Justice 2011). At other times the Crown is a Treaty negotiator working on a deed of settlement, an oTs official, or a Cabinet minister who holds one of the great offices of state. What all these figures share in common is that they are, in some way or other, legal embodiments of the state, or manifestations of sovereign power - albeit in an age when the 'sovereign' holds only symbolic power and is 'told what to do' by her ministers. In this respect, while the Crown is an extremely powerful entity and the ultimate source of all rights, it cannot 'speak for itself' but is always spoken for - usually by members of the executive. In this sense the Crown is a political and legal fiction. Like the concept of the state, it is hard to pin down or locate with any precision. Rather than regarding the Crown as a stable ontological entity, it is more analytically productive to examine its effects and focus on the political and symbolic functions it performs.

As we have sought to illustrate, the Crown fulfils a number of important political, legal and symbolic functions that go beyond the creation of a sense of unity or New Zealand nationhood. For citizens who have a grievance against the government, it provides a mechanism for holding the state to account and seeking compensation for past offences. In this sense, far from enabling governments 'to distance themselves from direct responsibility for obligations under the Treaty' (Wilson 2011, 1), it could be argued that the Crown renders government more responsible for past breaches of Treaty obligations. It also provides a convenient scapegoat: someone for the government to blame for wrongdoings of previous settler governments, from whom redress can be sought. For Māori claimant groups the Crown provides a higher authority to appeal to that sits over and above the ephemeral government of the day. Governments come and go and are driven by short-term agenda, but the Crown is seen as constant and unchanging; an entity that provides temporal continuity between the political regimes of the past, present and future. The Crown also endows the anonymous New Zealand state with a recognizable persona - giving face to an otherwise faceless and shifting set of bureaucratic offices.

However, while the Crown provides a useful vehicle for maintaining a sense of historical connectedness, one of the side-effects of this is to 'flatten history' and obscure the past by ignoring important distinctions between previous governments and their policies. The Crown in 1840 was fundamentally different to the Crown in 1945,1984 or 2008 . Yet from a legal perspective, it is essentially the same Crown as there has been no radical constitutional rupture in New Zealand: like the doctrine of apostolic succession, the spirit and authority of the Crown seems to pass relatively unchanged from generation to generation. But as many of our interviewees pointed out, this fiction has served New 
Zealand well.

We also found that both Māori and government make tactical use of the Crown. It is in neither party's interest to be too precise about its definition and meaning for its ambiguity is itself a political resource. The Crown offers a convenient 'Other' for both parties: for Māori it provides a focus for the settlement of claims and grievances; for the government (and the New Zealand state) it provides a vehicle by which the state can enter into conversation with itself. It enables the state to present itself as an entity distant from the government of the day. This can be very useful for resolving historical grievances against omissions and commissions of the Crown or in post-earthquake emergency situations. In short, the Crown evokes the idea of a higher authority and this can be extremely useful in situations where governments need to avoid accusations of bias or perceptions of a conflict of interest. An example of this is the use of public enquiries or 'Royal Commissions' for addressing issues where the government needs to be seen as neutral.

Finally, it should not be forgotten that the Crown, as the legal embodiment of the New Zealand state, is also the employer of all government staff and owner of all state lands, buildings and equipment and state owned companies. It gives the seal of approval for ratifying government legislation and international treaties. And it is also the body that confers prestigious official honours and titles in recognition of the achievements of New Zealand citizens. Few entities play such an important role in the constitutional order of New Zealand and in the popular imaginary of its citizens, yet few concepts, it seems, remain so ambiguous and problematic.

\section{ACKNOWLEDGEMENT}

This project was funded by Te Wharekura, a research initiative of the Faculty of Arts, University of Auckland, which aims to promote research into indigenous knowledges, peoples and identities. Fieldwork for the project took place between March and November 2012. We would like to thank the Te Wharekura team for their help in supporting the project. We also wish to thank the anonymous reviewers for SITES for their constructive comments on an earlier version of this article.

NOTES

1 This work is currently underway and is being carried out through a Royal Society of New Zealand Marsden Fund project (2014-2017) led by Shore and Williams. 
2 As defined in the Public Finance Act 1989 (s.2), the Crown includes 'all Ministers of the Crown and all departments' - the latter meaning 'any department or instrument of the government, or any branch or division thereof.. See also Joseph 2007; High Court of New Zealand, 2012. CIV-2006-404-003321, NZHC 3615 Judgement of Justice Duffy, 21 December 2012: (s.121).

\section{REFERENCES}

Anderson, Benedict. 1983. Imagined Communities: Reflections on the Origins and Spread of Nationalism. London: Verso.

Cohen, Anthony. 1985. The Symbolic Construction of Community, London: Routledge.

Cox, Noel. 2008. 'The Legitimacy of government and the normative Influence of the Crown on a political construct.' Paper presented at the 43rd Association of Law Teachers Conference, St. Anne’s College, University of Oxford.

Das, Veena and Deborah Poole. 2004. 'The State and its Margins.' In Anthropology at the Margins of the State,edited by Veena Das and Deborah Poole, 2-32. New Delhi: Oxford University Press.

Eriksen, Thomas Hylland. 2002. Ethnicity and Nationalism: Anthropological Perspectives. London: Pluto Press.

Gellner, Ernest. 1983. Nations and Nationalism. Oxford: Oxford University Press.

Joseph, Philip. 2007 Constitutional and Administrative Law in New Zealand (3rd edition). Wellington: Brookers.

Kelly, John and Martha Kaplan. 2001. 'Nation and Decolonization: Toward a New Anthropology of Nationalism.' Anthropological Theory 1 (4): 419-437.

Kertzer, David. 1988, Ritual, Politics and Power. New Haven: Yale University Press.

McHugh, Paul and Lisa Ford. 2013. 'Settler Sovereignty and the Shapeshifting Crown'. In Between Indigenous and Settler Governance, edited by Lisa Ford and Tim Rowse, 23-34. Abingdon: Oxon and New York: Routledge.

McLean, Janet. 2008. "Crown him with many crowns': the Crown and the Treaty of Waitangi.' New Zealand Journal of Public and International Law 6 (1):34-58. 
Mitchell, Timothy. 1991. 'The limits of the state: beyond statist approaches and their critics.' American Political Science Review, 85 (1):77-96.

Ministry of Justice (New Zealand), 2011. 'Crown Law Office.' Directory of Official Information, accessed 19 February 2014, http://www.justice.govt.nz/publications/global-publications/d/directory-of-official-information-archive/ directory-of-official-information-december-2009/alphabetical-list-of-entries-1/c/crown-law-office.

Rapport, Nigel. 2012. 'The Interview as a Form of Talking-partnership: Dialectical, Focussed, Ambiguous, Special.' In The Interview: An Ethnographic Approach, edited by Jonathan Skinner, 53-68. London: Berg.

Rose, Nikolas and Peter Miller. 1992. 'Political power beyond the state: Problematics of government.' British Journal of Sociology 43 (2):173-205.

Shore, Cris. 2006. 'Government Without Statehood'? Anthropological Perspectives on Governance and Sovereignty in the European Union.' European Law Journal 12 (6): 709-724.

Skinner, Jonathan, 'A Four Part Introduction to the Interview: Introducing the Interview; Society, Sociology and the Interview; Anthropology and the Interview; Anthropology and the Interview', in The Interview: An Ethnographic Approach, edited by Jonathan Skinner London: Berg: 1-49.

Steinmetz, George, ed. 1999. State/Culture. State-Formation After the Cultural Turn. Ithaca and London: Cornell University Press.

Supreme Court of New Zealand Decisions, 'Attorney-General v Mervyn Chapman 2010.' SC 120/2009 [2010] NZSC 31:10. http://www.courtsofnz.govt.nz/from/ decisions/judgments-supreme/judgments-supreme-2010

Trouillot, Michel Rolph. 2011. 'The Anthropology of the State in the Age of Globalization: Close Encounters of the Deceptive Kind.' Current Anthropology 42 (1):125-138.

Walzer, Michael. 1967. 'On the Role of Symbolism in Political Thought.' Political Science Quarterly 82 (2):191-204.

Wilson, Margaret. 2011. 'Treaty Settlement Process for Historical Grievances Relating to Land 1999-2005: A Crown Perspective from a Former Minister.' Paper 
Article · Shore \& Kawharu

presented at the conference Between Indigenous and Settler Governance, Sydney, University of Western Sydney, 18-20 August. 